\title{
Article \\ Geochemical Characterization of Intraplate Magmatism from Quaternary Alkaline Volcanic Rocks on Jeju Island, South Korea
}

\author{
Cheolhong Kim ${ }^{1}$, Naing Aung Khant ${ }^{1}$, Yongmun Jeon ${ }^{2} \mathbb{D}$, Heejung Kim ${ }^{3} \mathbb{D}$ and Chungwan Lim ${ }^{1, *}$ \\ 1 Department of Earth Science Education, Kongju National University, 56 Kongju-Daehak-Ro, Kongju, \\ Chungnam 32588, Korea; cheolhong@smail.kongju.ac.kr (C.K.); \\ naingaungkhantgeology@kongju.ac.kr (N.A.K.) \\ 2 Jeju Heritage Management Division, Jeju Special Self-Governing Province, Jeju 63341, Korea; \\ ymjeon74@korea.kr \\ 3 Department of Geology, Kangwon National University, Chuncheon 24341, Korea; \\ hydroqueen@kangwon.ac.kr \\ * Correspondence: tephra@kongju.ac.kr; Tel.: +82-41-850-8298
}

check for updates

Citation: Kim, C.; Khant, N.A.; Jeon, Y.; Kim, H.; Lim, C. Geochemical Characterization of Intraplate Magmatism from Quaternary Alkaline Volcanic Rocks on Jeju Island, South Korea. Appl. Sci. 2021, 11, 7030. https://doi.org/ 10.3390/app11157030

Academic Editors: Andrea L. Rizzo and François Beauducel

Received: 21 June 2021

Accepted: 28 July 2021

Published: 30 July 2021

Publisher's Note: MDPI stays neutral with regard to jurisdictional claims in published maps and institutional affiliations.

Copyright: (c) 2021 by the authors. Licensee MDPI, Basel, Switzerland. This article is an open access article distributed under the terms and conditions of the Creative Commons Attribution (CC BY) license (https:/ / creativecommons.org/licenses/by/ $4.0 /)$.
Abstract: The major and trace elements of Quaternary alkaline volcanic rocks on Jeju Island were analyzed to determine their origin and formation mechanism. The samples included tephrite, trachybasalts, basaltic trachyandesites, tephriphonolites, trachytes, and mantle xenoliths in the host basalt. Although the samples exhibited diversity in $\mathrm{SiO}_{2}$ contents, the relations of $\mathrm{Zr}$ vs. $\mathrm{Nb}$ and La vs. $\mathrm{Nb}$ indicated that the rocks were formed from the fractional crystallization of a single parent magma with slight continental crustal contamination ( $\mathrm{r}$ : $0-0.3$ by AFC modeling), rather than by the mixing of different magma sources. The volcanic rocks had an enriched-mantle-2-like ocean island basalt signature and the basalt was formed by partial melting of the upper mantle, represented by the xenolith samples of our study. The upper mantle of Jeju was affected by arc magmatism, associated with the subduction of the Pacific Plate beneath the Eurasian Plate. Therefore, we inferred that two separate magmatic events occurred on Jeju Island: one associated with the subduction of the Pacific Plate beneath the Eurasian Plate (represented by xenoliths), and another associated with a divergent setting when intraplate magmatism occurred (represented by the host rocks). With AFC modeling, it can be proposed that the Jeju volcanic rocks were formed by the fractional crystallization of the upper mantle combined with assimilation of the continental crust. The xenoliths in this study had different geochemical patterns from previously reported xenoliths, warranting further investigations.

Keywords: Jeju Island; alkaline volcanic rock; rare-earth element; oceanic island basalt; Quaternary

\section{Introduction}

Jeju Island lies approximately $90 \mathrm{~km}$ south of the Korean Peninsula and has a maximum elevation of $1950 \mathrm{~m}$ above sea level. It is an elliptical island, $73 \mathrm{~km}$ in length and $31 \mathrm{~km}$ in width, and is characterized by thick voluminous basaltic lava flows, minor pyroclastic rocks, and numerous small monogenetic volcanoes [1]. The volcanic rocks form a continuous series of alkali/sub-alkaline basalt-trachyte associations. The geology of Jeju Island has been studied by many researchers since 1925 [2-10]. Two separate magmatic events occurred on Jeju Island. The first was associated with the subduction of the Pacific Plate beneath the Eurasian Plate during the late Cretaceous and early Tertiary, while the other was associated with an extensional tectonic setting and is represented by Quaternary intraplate magmatism [11-14].

Over the last two decades, the Quaternary volcanic rocks on Jeju Island, comprising alkaline and sub-alkaline rocks formed by intraplate volcanism in a continental margin setting, have been studied [15-18]. Based on stratigraphic relationships, the volcanic activity of Jeju Island can be divided into four stages [16,19-21]: the first stage that formed 
the Seoguipo Formation and basal basalts, the second 'lava plateau' stage, the third 'shield' stage that created Mt. Halla and formed the bulk of the island, and the final 'scoria cone' stage that generated the dispersed small-volume vents visible on the surface [9]. In contrast, based on the geochemical development, Brenna et al. (2015) divided the volcanism into three main stages associated with changes in the depth and degree of partial melting of magma, with two sub-stages based on chemical differences observed in drill cores. Stage 1 produced high-Al alkaline basalts (stage $1 \mathrm{~b}$ ) and derivative evolved trachytic lavas (stage 1t), stage 2 produced high- $\mathrm{Al}$ and low-Al alkaline basalts, and stage 3 included the contemporaneous extrusion of primitive low-Al alkaline and sub-alkaline magmas (stage $3 b)$ and evolved trachytes (stage 3t) [14].

The volcanic activity on Jeju Island began at $<1.9 \mathrm{Ma}$ and persisted until $\sim 1000$ C.E. [9,16-18]. Geochemical studies using Sr-Nd-Pb radiogenic isotope ratios can help determine the genesis of these volcanic rocks $[17,22]$. Based on $\mathrm{Sr}-\mathrm{Nd}-\mathrm{Pb}$ isotopic systematics, the mantle source for Jeju volcanism has been characterized as a mixture of depleted mid-ocean ridge basaltic (MORB) mantle (DMM) and enriched-mantle-type-2 (EM2) components [16,17].

Woo et al. (2014) proposed that the isotopic signatures of the enriched-mantle (EM1EM2) source beneath East Asia are from recycling of the sub-continental lithosphere, oceanic crust, and/or subducted sediment [13]. Moreover, the recycling of those source materials is related to late Cretaceous to early Tertiary magmatism caused by the subduction of the Pacific Plate beneath the Eurasian Plate prior to the opening of Cenozoic back-arc basins [22-24].

Two chemically distinct magma series (alkaline and sub-alkaline) have accumulated on Jeju Island during the Quaternary period to form voluminous volcanic deposits $[9,16,25]$.

Previous studies on Jeju volcanic rocks have focused on the history of volcanism, the magma sources, and the tectonic settings [14,16,18,21,26-28]. Our study, additionally, aimed at investigating the underlying mechanism in the generation of the evolved volcanic rocks (trachybasalt to trachyte) on the island.

\section{Geologic Setting}

Jeju Island is a symmetrical shield-shaped volcanic edifice, the peak of which is located at Mt. Halla (1950 m). Topographically, the volcanic landforms can be divided into the lava plateau, the shield-shaped Halla volcanic edifice, and more than 360 monogenetic volcanoes [1,29]. Quaternary volcanism occurred on 25-35 km-thick continental crust [30], which is located $\sim 650 \mathrm{~km}$ behind the Ryukyu Trench/Nankai Trough where the Philippine Sea Plate subducts below the Eurasian Plate. The lithosphere beneath Jeju Island is estimated to be $\sim 60 \mathrm{~km}$ thick [21,31].

The geology of the island is characterized by lavas ranging from basaltic to trachytic. The lavas occur extensively on the island together with diverse volcanic landforms, including Mt. Halla at the center of the island and about 360 volcanic cones that are scattered throughout the island. In the subsurface, phreatomagmatic volcanoes (tuff rings and tuff cones) produced by explosive hydrovolcanic activity occur extensively, together with intervening volcaniclastic sedimentary deposits $[1,32,33]$.

Researchers have previously studied the petrography of volcanic rocks from Jeju Island $[16,28]$. On Jeju Island, lava flows display a compositional spectrum from alkali basalt/basanite to trachyte. Less-evolved rocks (basalt to trachybasalt) generally consist of phenocrysts of clinopyroxene and olivine in modal abundances of $<15 \%$; the groundmass comprises plagioclase, olivine, and clinopyroxene microlites, with or without dispersed titanomagnetite. The more evolved rocks (basaltic trachyandesite) contain phenocryst phase of plagioclase and groundmass of alkali-feldspar microlites [28]. On examining the samples from deep cores (400-500 m) of the central Jeju Island, dominant phenocryst assemblages were visible in the hand specimens. These varied systematically from the olivine-and-pyroxene-dominated base to a plagioclase-rich top. Tatsumi et al. (2005) 
reported that, in Jeju basalts, spinel crystals were included in olivine phenocrysts. This is indicative of the equilibrium of basalt magmas with the residual spinel in the mantle [16].

The volcanism of Jeju Island comprises the syn-depositional $(\sim 1.88-0.5 \mathrm{Ma})$ and post-depositional (0.5 Ma) Holocene Seoguipo Formation, which is composed of basaltic volcaniclastics and fossiliferous deposits. The syn-depositional volcanism is characterized by hydrovolcanism with minor alkali basaltic lava effusions ( 1 Ma), domed extrusions with evolved alkaline lavas, and alkaline lava effusions that erupted locally and sporadically during the deposition of the Seoguipo Formation. The post-depositional volcanism is characterized by extensive terrestrial volcanism after the termination of the deposition of the Seoguipo Formation at $\sim 0.5 \mathrm{Ma}$ [18].

The basement rocks of Jeju Island include granites and silicic volcanic rocks of Jurassic to Cretaceous age, as well as gneisses of unknown age that were observed in drill cores as xenoliths in the basalts and tuffs $[9,16,17,20,21]$. Mantle xenoliths are observed within volcanic rocks distributed extensively on Jeju Island and include spinel peridotites and pyroxenites [21,27,34], as well as gabbroic and anorthite xenoliths [11-13,20,21,34,35].

\section{Analytical Methods}

Ten fresh rock samples from trachyte outcrops and two samples of mantle xenoliths from basalts were collected for analysis (Figure 1). Fresh whole-rock samples were cut down into chips, which were then cleaned ultrasonically in distilled water with $<5 \% \mathrm{HNO}_{3}$, and then in distilled water only. The chips were then dried and handpicked to avoid visible contamination. The weathered rims were removed, and all of the chips were crushed to a millimeter scale. The crushed chips containing no xenocrysts or amygdules were handpicked under a magnifier. Only fresh rock chips without any xenocrysts or amygdules were selected for further analyses. An agate mill was used to crush and pulverize the samples, and the resulting powders were analyzed to determine their major and traceelemental compositions. The trachytic specimens were sent to the Center for Research Facilities, Chonnam National University, for major elemental analysis using an X-ray fluorescence spectrometer (PW1480, Philips). The relative error rates reported from the analyses using a standard sample (BHVO- 1 ) were $<1 \%$ for $\mathrm{Si}, \mathrm{Ti}, \mathrm{Al}, \mathrm{Mg}, \mathrm{Ca}$, and $\mathrm{Na}$; $1-2 \%$ for $\mathrm{Fe}, \mathrm{K}$, and $\mathrm{P}$; and 2-3\% (one standard deviation; $1 \sigma$ ) for $\mathrm{Mn}$.

The samples were sent to the National Center for Inter-University Research Facilities, Seoul National University, for trace-elemental analysis using inductively coupled plasma mass spectrometry (ICP-MS; ELAN 6100, Perkin-Elmer SCIEX) with an argon plasma source $(6000 \mathrm{~K})$ and a mass resolution of $0.3-3.0 \mathrm{amu}$. The comparison between the average and recommended values obtained from repeated analyses of BHVO-1 exhibited relative error rates of $12 \%$ for $\mathrm{Er}$ and $\mathrm{Ho} ;<5 \%$ for $\mathrm{Ba}, \mathrm{Cr}, \mathrm{Cu}, \mathrm{Nb}, \mathrm{Sr}, \mathrm{Rb}, \mathrm{Y}, \mathrm{Zr}, \mathrm{La}, \mathrm{Ce}, \mathrm{Sm}$, and $\mathrm{Lu}$; and $5-10 \%$ for $\mathrm{Nd}, \mathrm{Eu}, \mathrm{Gd}, \mathrm{Pr}, \mathrm{Tb}, \mathrm{Dy}$, and $\mathrm{Yb}$. 


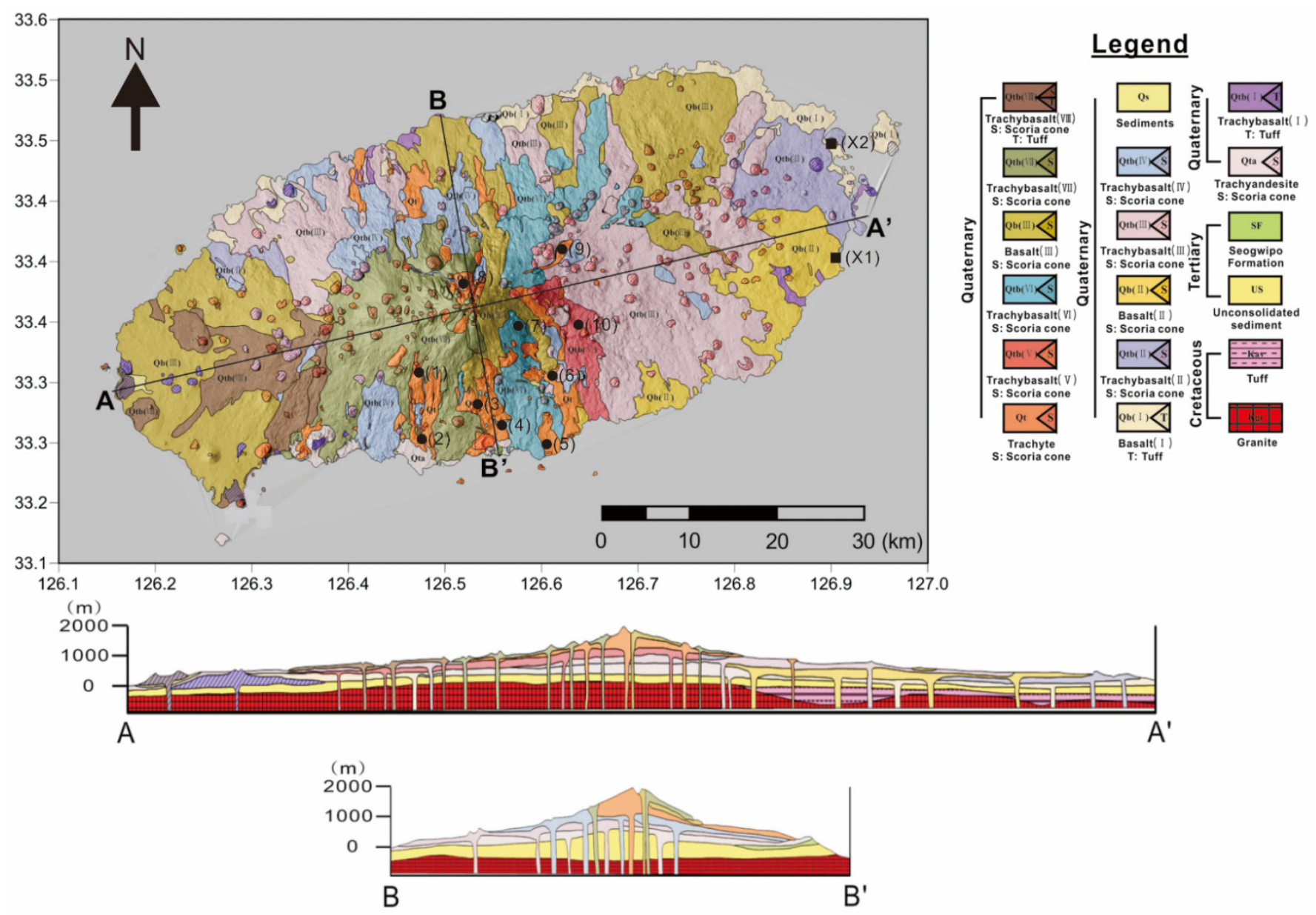

Figure 1. Geologic map of Jeju Island (modified from Park et al., 2000) [36] with the sampling locations of trachytic rocks (1 10) and mantle xenoliths (X1 2).

\section{Results}

\subsection{Major Elements}

The major and trace-elemental compositions of the samples are presented in Table 1. Based on the $\mathrm{SiO}_{2}$ vs. $\mathrm{K}_{2} \mathrm{O}+\mathrm{Na}_{2} \mathrm{O}$ classification diagram of Bas et al. (1986) [37], the volcanic rock samples were classified as basaltic trachyandesites, trachyandesites, tephrites, tephriphonolites, and trachytes (Figure 2). Half of the samples were basaltic trachyandesites. All of the analyzed samples were in the alkaline region of the diagram, even though two chemically distinct (alkaline and sub-alkaline) magma series are present on Jeju Island (Figure 2) [14,16,18].

The basaltic trachyandesites (Samples 1, 2, 6, 8, and 9) contained SiO (49.73-51.95 wt.\%), $\mathrm{Na}_{2} \mathrm{O}\left(6.23-5.89\right.$ wt.\%), and $\mathrm{K}_{2} \mathrm{O}(2.19-1.38$ wt.\%). The tephrite (samples 3 and 7 ) exhibited the lowest $\mathrm{SiO}_{2}$ contents (47.82-48.21 wt.\%), $\mathrm{Na}_{2} \mathrm{O}$ contents (5.99-6.49 wt.\%), and $\mathrm{K}_{2} \mathrm{O}$ contents (1.39-2.19 wt.\%). The trachybasalt (sample no. 5) had an $\mathrm{SiO}_{2}$ content of 50.126 wt.\%, a $\mathrm{Na}_{2} \mathrm{O}$ content of 5.32 wt. $\%$, and a $\mathrm{K}_{2} \mathrm{O}$ content of 0.89 wt.\%. The tephriphonolite (sample no. 10) contained $\mathrm{SiO}_{2}$ (55.21 wt.\%), $\mathrm{Na}_{2} \mathrm{O}$ (7.87 wt.\%), and $\mathrm{K}_{2} \mathrm{O}$ (3.45 wt.\%). Trachyte, which was the most felsic sample (Sample No. 4), had an $\mathrm{SiO}_{2}$ content of 61.94 wt.\%, a $\mathrm{Na}_{2} \mathrm{O}$ content of 8.79 wt.\%, and a $\mathrm{K}_{2} \mathrm{O}$ content of $5.01 \mathrm{wt} \%$. All of the samples fell along the Na-series, since the $\mathrm{Na}_{2} \mathrm{O} / \mathrm{K}_{2} \mathrm{O}$ values were $1.76-6.01$. In an AFM diagram, the samples plotted near the boundary between the calc-alkaline and tholeiitic fields (Figure 3). The AFM diagram displays the fractional crystallization trend, which will be explained in detail later. 
Table 1. Major and trace-elemental compositions of Jeju Island alkaline volcanic rocks.

\begin{tabular}{|c|c|c|c|c|c|c|c|c|c|c|c|c|}
\hline Sample & 1 & 2 & 3 & 4 & 5 & 6 & 7 & 8 & 9 & 10 & X1 & $\mathrm{X} 2$ \\
\hline Rock Type $^{1}$ & BTA & BTA & $\mathrm{Te}$ & $\operatorname{Tr}$ & TB & BTA & $\mathrm{Te}$ & BTA & BTA & TP & Xe & $\mathrm{Xe}$ \\
\hline \multicolumn{13}{|l|}{ wt. $\%$} \\
\hline $\mathrm{SiO}_{2}$ & 51.95 & 49.90 & 47.82 & 61.94 & 50.13 & 51.85 & 48.21 & 49.73 & 50.43 & 55.21 & 40.08 & 42.70 \\
\hline $\mathrm{Al}_{2} \mathrm{O}_{3}$ & 16.77 & 17.74 & 16.76 & 16.84 & 15.85 & 17.35 & 15.89 & 15.91 & 17.50 & 18.20 & 1.97 & 2.35 \\
\hline $\mathrm{Na}_{2} \mathrm{O}$ & 6.17 & 5.95 & 6.49 & 8.80 & 5.32 & 6.23 & 5.99 & 5.89 & 6.23 & 7.87 & 0.13 & 0.23 \\
\hline $\mathrm{Fe}_{2} \mathrm{O}_{3}{ }^{2}$ & 11.37 & 10.50 & 11.47 & 3.49 & 11.50 & 8.89 & 12.26 & 12.49 & 10.47 & 6.57 & 10.74 & 9.96 \\
\hline $\mathrm{CaO}$ & 6.05 & 9.06 & 8.67 & 2.58 & 9.53 & 8.15 & 8.73 & 8.03 & 8.54 & 5.62 & 1.46 & 1.83 \\
\hline $\mathrm{K}_{2} \mathrm{O}$ & 2.13 & 1.40 & 1.28 & 5.01 & 0.89 & 2.20 & 1.51 & 1.43 & 1.39 & 3.45 & 0.05 & 0.08 \\
\hline $\mathrm{TiO}_{2}$ & 2.15 & 2.40 & 2.64 & 0.47 & 2.11 & 1.88 & 2.58 & 2.22 & 2.27 & 1.23 & 0.08 & 0.12 \\
\hline $\mathrm{MgO}$ & 2.10 & 2.20 & 3.86 & 0.23 & 4.08 & 2.72 & 3.90 & 3.46 & 2.20 & 0.88 & 45.06 & 42.36 \\
\hline $\mathrm{P}_{2} \mathrm{O}_{5}$ & 0.93 & 0.50 & 0.66 & 0.12 & 0.25 & 0.43 & 0.61 & 0.47 & 0.63 & 0.43 & nd & nd \\
\hline $\mathrm{MnO}$ & 0.17 & 0.13 & 0.16 & 0.23 & 0.15 & 0.11 & 0.17 & 0.17 & 0.14 & 0.24 & 0.13 & 0.12 \\
\hline Total & 99.78 & 99.79 & 99.80 & 99.70 & 99.80 & 99.79 & 99.83 & 99.80 & 99.79 & 99.71 & 99.70 & 99.75 \\
\hline $\mathrm{Mg} \#^{3}$ & 34.32 & 37.28 & 48.79 & 15.74 & 50.12 & 46.44 & 47.37 & 44.00 & 37.29 & 27.56 & 92.24 & 92.33 \\
\hline \multicolumn{13}{|c|}{ Concentrations in ppm } \\
\hline Sc & 10.67 & 12.68 & 14.57 & nd & 14.37 & 7.21 & 12.94 & 14.80 & 10.64 & 3.18 & 0.69 & 1.02 \\
\hline $\mathrm{La}$ & 39.54 & 22.71 & 26.69 & 113.39 & 17.38 & 25.44 & 20.33 & 24.12 & 20.96 & 79.74 & 0.69 & 1.02 \\
\hline $\mathrm{Ce}$ & 81.16 & 45.82 & 53.19 & 206.62 & 35.22 & 47.52 & 41.82 & 49.80 & 42.20 & 147.15 & 1.40 & 1.67 \\
\hline $\operatorname{Pr}$ & 9.74 & 5.70 & 6.58 & 20.84 & 4.44 & 5.69 & 5.25 & 6.06 & 5.26 & 16.01 & 0.16 & 0.25 \\
\hline $\mathrm{Nd}$ & 40.14 & 24.13 & 27.50 & 67.80 & 19.34 & 22.12 & 22.21 & 25.25 & 22.51 & 55.41 & 0.65 & 0.99 \\
\hline $\mathrm{Sm}$ & 9.05 & 5.76 & 6.36 & 11.99 & 5.09 & 5.05 & 5.17 & 6.23 & 5.53 & 10.52 & 0.16 & 0.25 \\
\hline $\mathrm{Eu}$ & 2.99 & 2.08 & 2.22 & 3.20 & 1.75 & 2.33 & 1.79 & 2.16 & 2.00 & 3.31 & 0.06 & 0.08 \\
\hline $\mathrm{Gd}$ & 9.76 & 6.49 & 7.08 & 13.02 & 5.89 & 5.40 & 5.75 & 7.07 & 6.30 & 11.31 & 0.21 & 0.32 \\
\hline $\mathrm{Tb}$ & 1.29 & 0.86 & 0.92 & 1.55 & 0.81 & 0.69 & 0.75 & 0.94 & 0.84 & 1.36 & 0.03 & 0.05 \\
\hline Dy & 6.53 & 4.44 & 4.70 & 7.96 & 4.29 & 3.46 & 3.87 & 4.90 & 4.31 & 6.92 & 0.21 & 0.32 \\
\hline Ho & 1.17 & 0.78 & 0.83 & 1.53 & 0.77 & 0.60 & 0.69 & 0.87 & 0.77 & 1.30 & 0.05 & 0.07 \\
\hline $\mathrm{Er}$ & 3.06 & 2.05 & 2.17 & 4.56 & 2.02 & 1.62 & 1.83 & 2.29 & 2.00 & 3.69 & 0.14 & 0.20 \\
\hline $\mathrm{Tm}$ & 0.37 & 0.25 & 0.26 & 0.85 & 0.25 & 0.20 & 0.22 & 0.28 & 0.24 & 0.49 & 0.02 & 0.03 \\
\hline $\mathrm{Yb}$ & 2.25 & 1.48 & 1.57 & 3.97 & 1.51 & 1.19 & 1.33 & 1.67 & 1.45 & 3.11 & 0.14 & 0.20 \\
\hline $\mathrm{Lu}$ & 0.31 & 0.21 & 0.22 & 0.60 & 0.21 & 0.17 & 0.19 & 0.24 & 0.20 & 0.46 & 0.02 & 0.03 \\
\hline $\mathrm{Zr}$ & 259.11 & 111.05 & 118.45 & 562.64 & 103.64 & 118.45 & 81.43 & 185.08 & 103.64 & 384.96 & 3.94 & 6.22 \\
\hline $\mathrm{Nb}$ & 41.94 & 20.97 & 27.96 & 83.88 & 13.98 & 27.96 & 20.97 & 27.96 & 20.97 & 69.90 & 0.97 & 1.34 \\
\hline $\mathrm{Rb}$ & 36.58 & 27.43 & 27.43 & 118.87 & 27.43 & 45.72 & 18.29 & 27.43 & 18.29 & 91.44 & & \\
\hline $\mathrm{Ba}$ & 483.48 & 277.56 & 268.60 & 787.90 & 223.84 & 510.34 & 349.18 & 304.42 & 295.46 & 671.51 & 9.12 & 9.78 \\
\hline Th & 6.10 & 3.28 & 3.72 & 16.19 & 2.86 & 4.51 & 2.26 & 3.31 & 3.06 & 11.05 & 0.12 & 0.19 \\
\hline $\mathrm{U}$ & & & & & & & & & & & 0.05 & 0.10 \\
\hline $\mathrm{Ta}$ & & & & & & & & & & & 0.12 & 0.14 \\
\hline $\mathrm{K}$ & & & & & & & & & & & 412.97 & 644.25 \\
\hline $\mathrm{Pb}$ & & & & & & & & & & & 0.27 & 0.40 \\
\hline $\mathrm{Sr}$ & 338.24 & 422.80 & 388.97 & 481.99 & 295.96 & 549.63 & 388.97 & 304.41 & 380.52 & 668.02 & 8.95 & 11.51 \\
\hline $\mathrm{Ti}$ & & & & & & & & & & & 484.22 & 702.62 \\
\hline $\mathrm{Y}$ & 27.21 & 19.70 & 20.14 & 40.39 & 18.93 & 16.35 & 14.07 & 20.58 & 17.61 & 32.66 & 1.35 & 2.05 \\
\hline$(\mathrm{La} / \mathrm{Sm})_{\mathrm{N}}$ & 2.73 & 2.46 & 2.62 & 5.91 & 2.13 & 3.15 & 2.46 & 2.42 & 2.37 & 4.73 & 2.64 & 2.57 \\
\hline$(\mathrm{La} / \mathrm{Lu})_{\mathrm{N}}$ & 13.05 & 11.32 & 12.60 & 19.58 & 8.57 & 15.71 & 11.28 & 10.53 & 10.67 & 17.99 & 3.09 & 3.41 \\
\hline$\left(\mathrm{Eu} / \mathrm{Eu}^{*}\right)$ & 0.97 & 1.04 & 1.01 & 0.78 & 0.97 & 1.36 & 1.00 & 0.99 & 1.03 & 0.93 & 0.90 & 0.86 \\
\hline$\left(\mathrm{Ce} / \mathrm{Ce}^{*}\right)$ & 1.00 & 0.97 & 0.97 & 1.03 & 0.97 & 0.96 & 0.98 & 1.00 & 0.97 & 1.00 & 1.02 & 0.81 \\
\hline \multicolumn{13}{|c|}{ CIPW normative mineralogy $(\text { wt. } \%)^{4}$} \\
\hline plag & 54.61 & 49.51 & 39.21 & 47.38 & 49.75 & 44.67 & 38.71 & 45.81 & 50.46 & 41.52 & 5.86 & 7.09 \\
\hline or & 12.59 & 8.27 & 7.56 & 29.61 & 5.26 & 13.00 & 8.92 & 8.45 & 8.21 & 20.39 & 0.30 & 0.47 \\
\hline ne & 5.08 & 9.96 & 15.45 & 6.15 & 6.50 & 11.33 & 12.99 & 9.09 & 9.72 & 15.83 & - & - \\
\hline $\mathrm{cpx}$ & 10.17 & 19.99 & 21.13 & 8.14 & 23.65 & 20.29 & 22.38 & 19.82 & 18.73 & 12.98 & 2.15 & 3.09 \\
\hline opx & - & - & - & - & - & - & - & - & - & - & 1.00 & 13.35 \\
\hline wo & - & - & - & 1.12 & - & - & - & - & - & 2.34 & - & - \\
\hline ol & 5.36 & 1.01 & 4.11 & - & 4.25 & 1.45 & 4.34 & 5.01 & 1.61 & - & 84.84 & 70.48 \\
\hline ac & - & - & - & 3.04 & - & - & - & - & - & - & - & - \\
\hline $\mathrm{ns}$ & - & - & - & 2.86 & - & - & - & & - & - & - & - \\
\hline
\end{tabular}


Table 1. Cont.

\begin{tabular}{cccccccccccccc}
\hline Sample & $\mathbf{1}$ & $\mathbf{2}$ & $\mathbf{3}$ & $\mathbf{4}$ & $\mathbf{5}$ & $\mathbf{6}$ & $\mathbf{7}$ & $\mathbf{8}$ & $\mathbf{9}$ & $\mathbf{1 0}$ & $\mathbf{X 1}$ & $\mathbf{X 2}$ \\
\hline Rock Type $^{\mathbf{1}}$ & BTA & BTA & Te & Tr & TB & BTA & Te & BTA & BTA & TP & Xe & Xe \\
\hline il & 4.08 & 4.56 & 5.01 & 0.89 & 4.01 & 3.57 & 4.90 & 4.22 & 4.31 & 2.34 & 0.15 & 0.23 \\
mt & 4.96 & 4.57 & 5.00 & - & 5.02 & 3.87 & 5.34 & 5.44 & 4.57 & 2.86 & 4.68 & 4.34 \\
ap & 2.15 & 1.16 & 1.53 & 0.28 & 0.58 & 1.00 & 1.41 & 1.09 & 1.46 & 1.00 & - & - & 90 \\
Total & 99.00 & 99.03 & 99.00 & 99.47 & 99.02 & 99.18 & 98.99 & 98.93 & 99.07 & 99.26 & 98.98 & 99.05 \\
\hline
\end{tabular}

${ }^{1}$ BTA: Basaltic andesite; Te: Tephrite; Tr: Trachyte; TB: Trachybasalt; TP: Tephriphonolite; Xe: Xenolith. ${ }^{2}$ Total iron as $\mathrm{Fe}_{2} \mathrm{O}_{3} .{ }^{3} \mathrm{Mg}^{\#}$ $\left[=100 \times \mathrm{Mg} /\left(\mathrm{Mg}+\mathrm{Fe}^{2+}\right)\right]$, assuming $\mathrm{Fe}^{2+} / \mathrm{Fe}_{\text {total }}=0.9 .{ }^{4}$ plag: Plagioclase; or: Orthoclase; ne: Nepheline; cpx: Clinopyroxene; opx: Orthopyroxene; wo: Wollastonite; ol: Olivine; ac: acmite; ns: Sodium metasilicate; il: Ilmenite; mt: Magnetite; ap: Apatite.

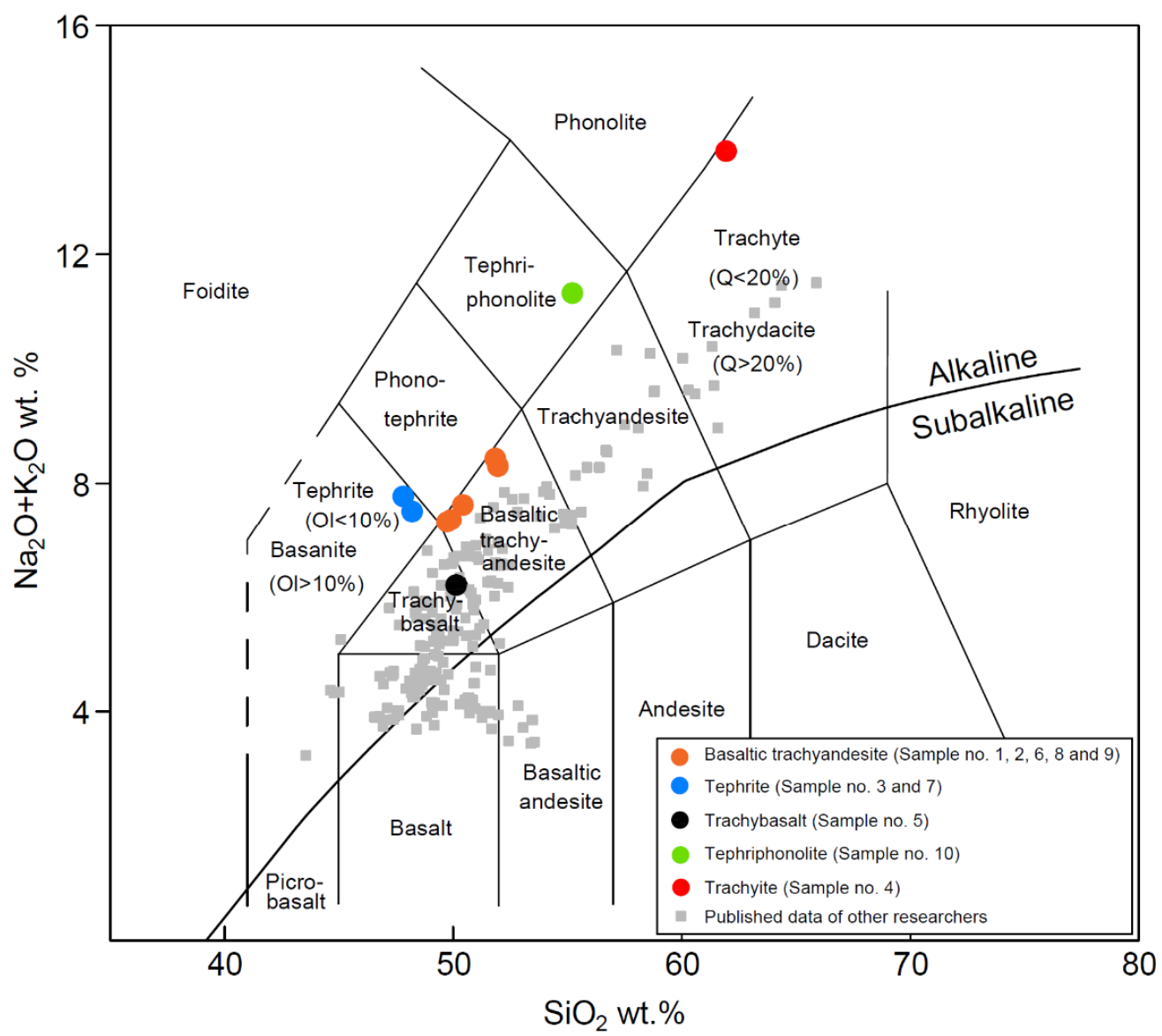

Figure 2. $\mathrm{SiO}_{2}$ vs. $\mathrm{K}_{2} \mathrm{O}+\mathrm{Na}_{2} \mathrm{O}$ classification (TAS) diagram of late Cenozoic volcanic rocks on Jeju Island [37]. Published data of other researchers are from Kim et al. (2019) and Brenna et al. (2012b) $[21,28]$.

As depicted in Harker diagrams of the variations in major oxide and $\mathrm{SiO}_{2}$ contents (Figure 4), the basaltic trachyandesite samples had low $\mathrm{MnO}, \mathrm{Na}_{2} \mathrm{O}$, and $\mathrm{K}_{2} \mathrm{O}$ contents, but it had high $\mathrm{Al}_{2} \mathrm{O}_{3}, \mathrm{Fe}_{2} \mathrm{O}_{3}, \mathrm{TiO}_{2}, \mathrm{CaO}, \mathrm{P}_{2} \mathrm{O}_{5}$, and $\mathrm{MgO}$ contents. The $\mathrm{P}_{2} \mathrm{O}_{5}$ content decreased as the $\mathrm{SiO}_{2}$ content increased and started to decrease at 53\% of $\mathrm{SiO}_{2}$ (Figure 4), suggesting the crystallization of apatite. The tephrite and trachybasalt samples had major oxide contents similar to those of the basaltic trachyandesites, except that trachybasalts had lower $\mathrm{P}_{2} \mathrm{O}_{5}$ and $\mathrm{Al}_{2} \mathrm{O}_{3}$ contents. However, the tephriphonolite and trachyte contained high $\mathrm{Na}_{2} \mathrm{O}$ and $\mathrm{K}_{2} \mathrm{O}$ contents and pronounced high $\mathrm{MnO}$ contents. The $\mathrm{Na}_{2} \mathrm{O}, \mathrm{K}_{2} \mathrm{O}$, $\mathrm{MnO}$, and $\mathrm{SiO}_{2}$ contents of the more felsic rocks, such as tephriphonolites and trachytes, were positively correlated. These two rock types also exhibited negative correlations of $\mathrm{Al}_{2} \mathrm{O}_{3}, \mathrm{Fe}_{2} \mathrm{O}_{3}, \mathrm{P}_{2} \mathrm{O}_{5}, \mathrm{MgO}, \mathrm{CaO}$, and $\mathrm{TiO}_{2}$ contents with $\mathrm{SiO}_{2}$ contents. The fractional crystallization of clinopyroxene and plagioclase is indicated by the negative correlation 
between $\mathrm{CaO}$ and $\mathrm{SiO}_{2}$ contents, and the positive correlation followed by the negative correlation between $\mathrm{Al}_{2} \mathrm{O}_{3}$ and $\mathrm{SiO}_{2}$ contents (Figure 4). The fractional crystallization of plagioclase was evident in the trachyte sample (sample no. 4), in which a negative $\mathrm{Eu} / \mathrm{Eu}^{*}$ anomaly was observed (Table 1 and Figure 5).

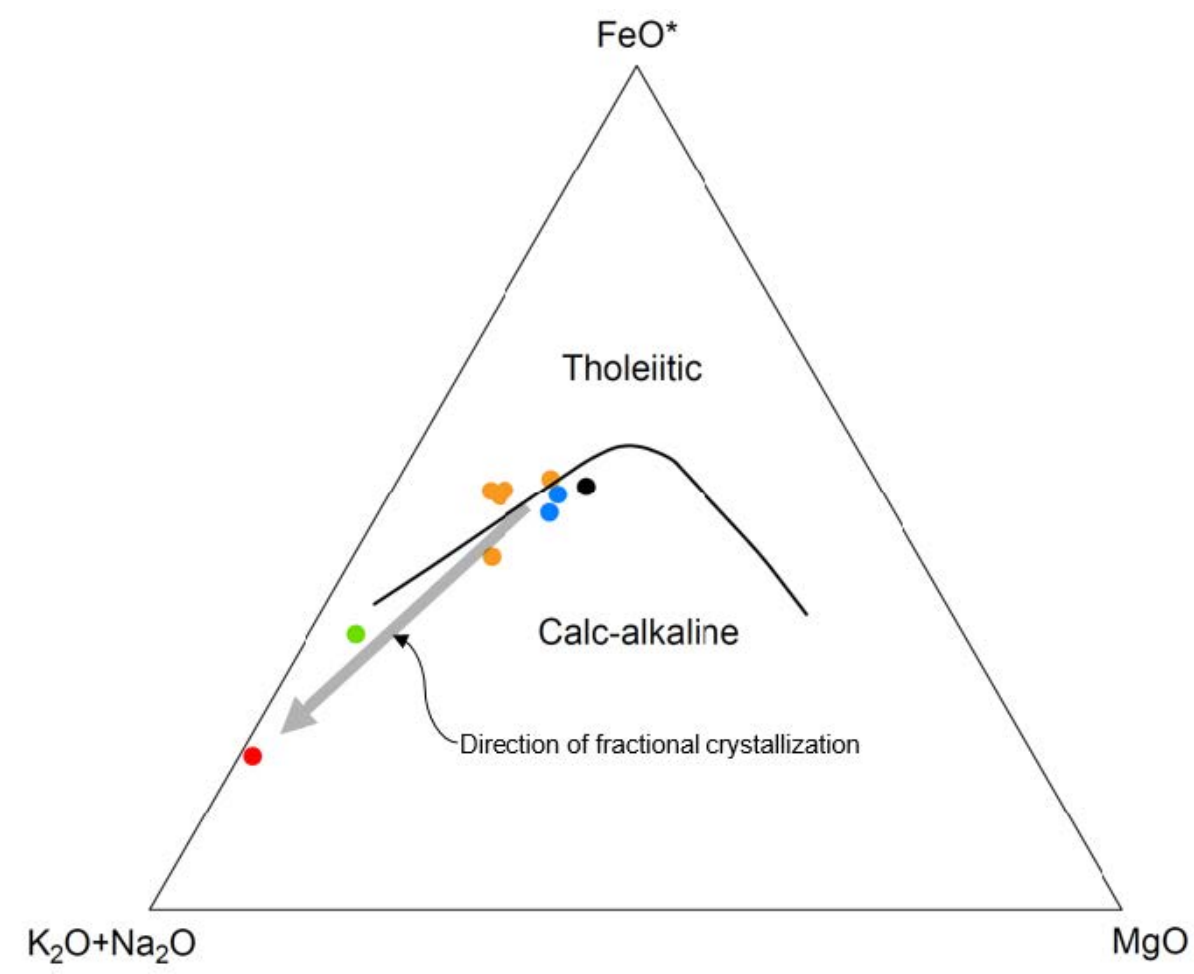

Figure 3. AFM diagram of late Cenozoic volcanic rocks on Jeju Island, including the boundary between the calc-alkaline and the tholeiitic fields (after Irvine and Baragar, 1971) [38]. Symbols are the same as in Figure 2. $\mathrm{FeO}^{*}$ is total iron as $\mathrm{FeO}$ assuming $\mathrm{Fe}^{2+} / \mathrm{Fe}_{\text {total }}=0.9$.

\subsection{Trace and Rare-Earth Elements}

The chondrite-normalized rare-earth-element (REE) plots for the volcanic rock samples from Jeju Island showed a notable enrichment in light REEs (LREEs) and a depletion of heavy REEs (HREEs) (Figure 5). The HREEs displayed a flat trend. The pattern resembles that of oceanic island basalts $(\mathrm{OIBs})[39]$, and the $(\mathrm{La} / \mathrm{Lu})_{\mathrm{N}}$ and $(\mathrm{La} / \mathrm{Sm})_{\mathrm{N}}$ ratios were 8.85-20.22 and 2.20-6.10, respectively. The trachyte sample (sample no. 4) exhibited a pronounced negative $\mathrm{Eu}$ anomaly $\left(\mathrm{Eu} / \mathrm{Eu}^{*}=0.78\right)$, whereas the other samples exhibited slightly negative and positive Eu anomalies $\left(\mathrm{Eu} / \mathrm{Eu}^{*}=0.93-1.37\right.$; Table 1$)$. The $\left(\mathrm{Ce} / \mathrm{Ce}^{*}\right)$ anomalies were steady and negative, with values of $0.92-0.97$, indicating that the volcanic rocks were not affected by oxidation.

The two most-evolved rocks (tephriphonolite and trachyte) contained higher concentrations of incompatible elements, in the form of the large-ion lithophile elements (LILEs) $\mathrm{Rb}$ and $\mathrm{Ba}$ and the high-field-strength elements (HFSEs) $\mathrm{Nb}$ and $\mathrm{Zr}$, than the other rock types analyzed in this study (Table 1 and Figure 6). The two xenolith samples displayed depletion of the trace elements and REEs compared to the alkaline volcanic rocks, but the patterns look similar to those of the volcanic rocks (Figures 5 and 6), which indicates their origins are linked. 

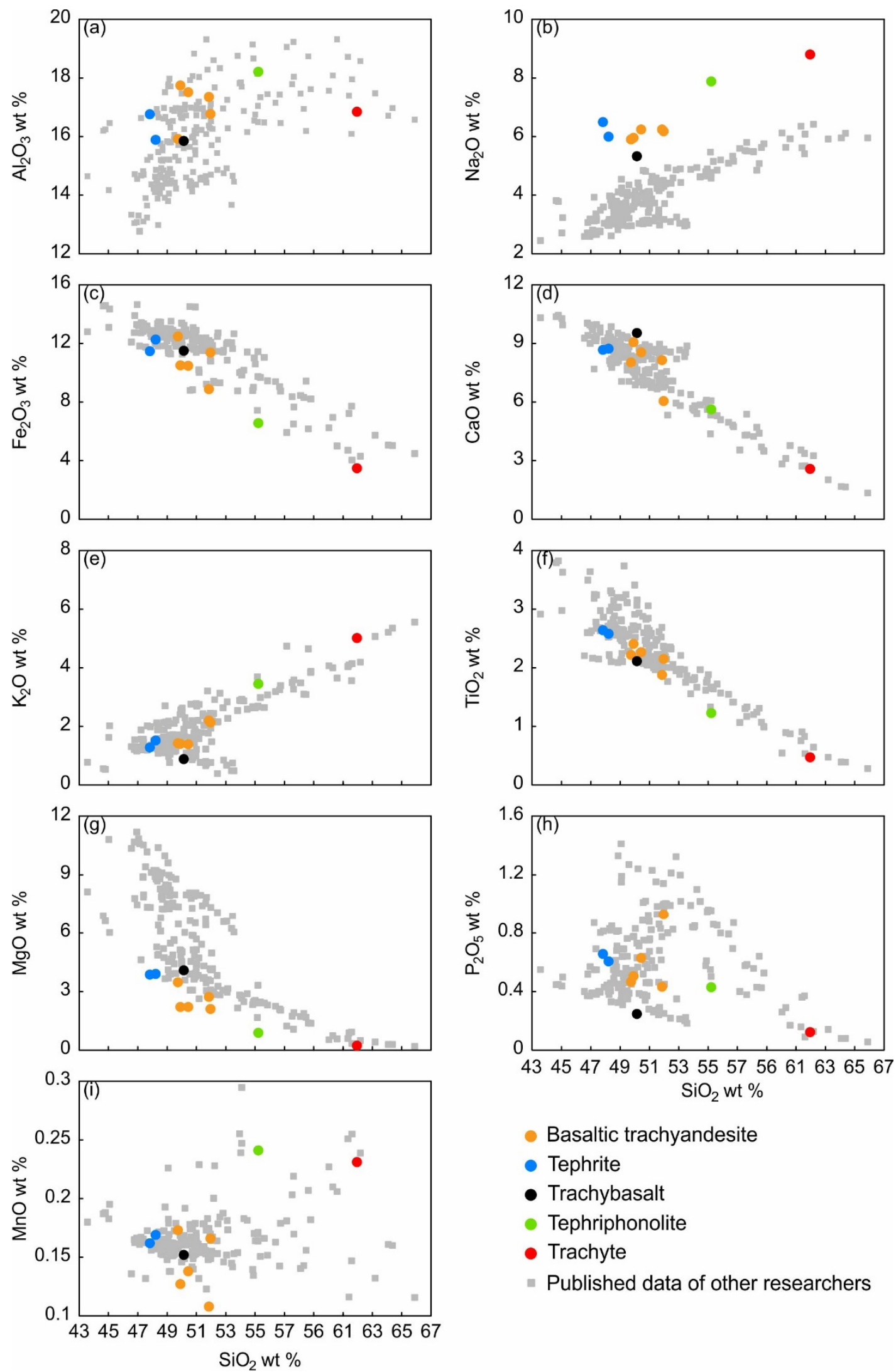

- Basaltic trachyandesite

- Tephrite

- Trachybasalt

- Tephriphonolite

- Trachyte

- Published data of other researchers

Figure 4. Variations in major oxide contents vs. $\mathrm{SiO}_{2}$ content of the volcanic rock samples from Jeju Island, $\mathrm{Al}_{2} \mathrm{O}_{3} \mathrm{vs}$. SiO (a), $\mathrm{Na}_{2} \mathrm{O}$ vs. $\mathrm{SiO}_{2}$ (b), $\mathrm{Fe}_{2} \mathrm{O}_{3 \text { total }}$ vs. $\mathrm{SiO}_{2}$ (c), $\mathrm{CaO}$ vs. $\mathrm{SiO}_{2}$ (d), $\mathrm{K}_{2} \mathrm{O}$ vs. $\mathrm{SiO}_{2}$ (e), $\mathrm{TiO}_{2}$ vs. $\mathrm{SiO}_{2}$ (f), $\mathrm{MgO}_{\text {vs. }} \mathrm{SiO} 2$ (g), $\mathrm{P}_{2} \mathrm{O}_{5}$ vs. $\mathrm{SiO}_{2}$ (h) and $\mathrm{MnO}$ vs. $\mathrm{SiO}_{2}$ (i). Published data of other researchers are from Kim et al. (2019) and Brenna et al. (2012b) [21,28]. 


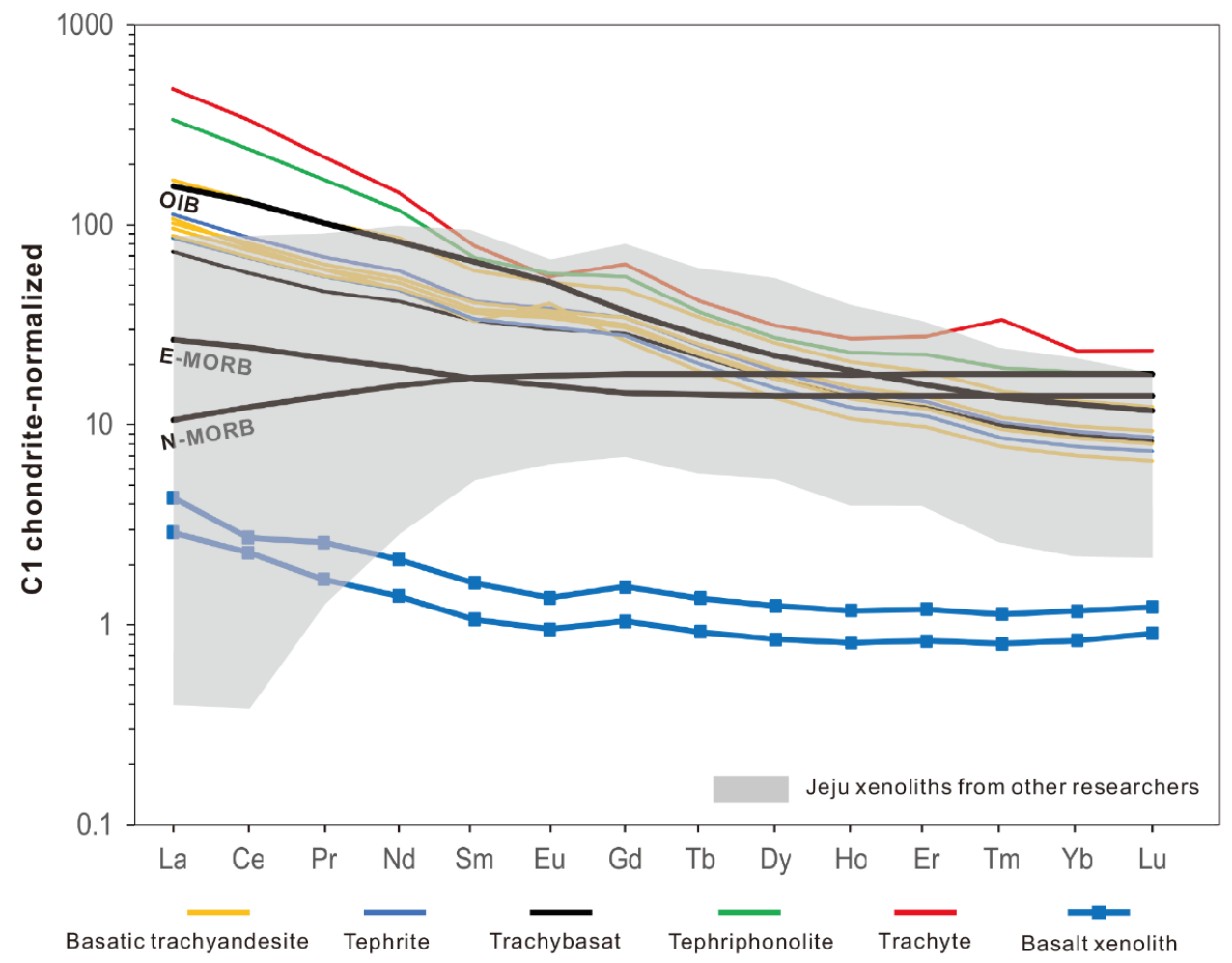

Figure 5. C1-chondrite-normalized [39] rare-earth-element patterns of alkaline volcanic rock and mantle xenolith samples from Jeju Island. The E-MORB, N-MORB, and OIB data are from Sun and McDonough (1989) [39]. The compiled xenolith data are from Yang et al., 2012a; Yang et al., 2012b; Woo et al., 2014 and Choi et al., 2005 [11-13,34].

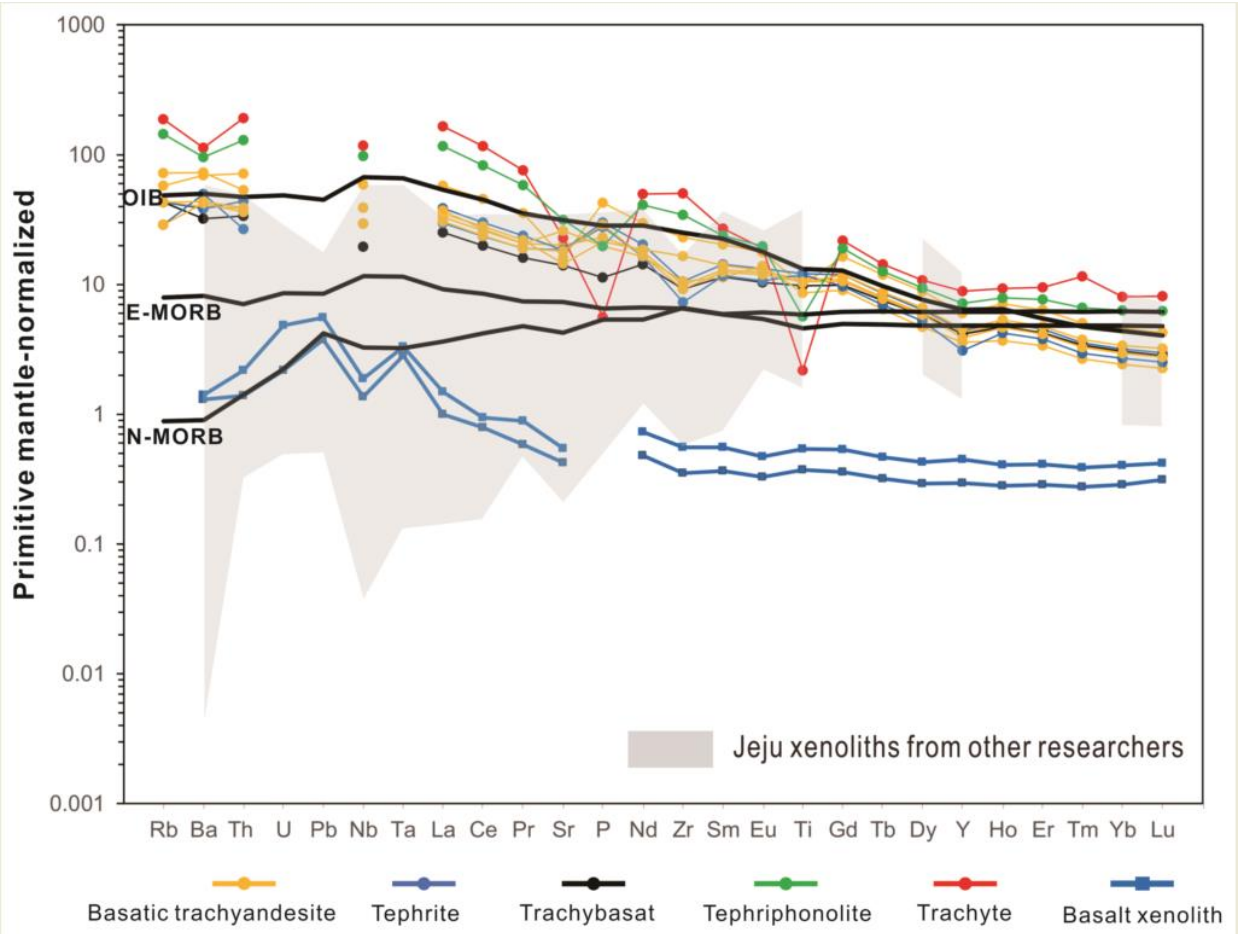

Figure 6. Primitive-mantle-normalized [39] multi-elemental spidergram. The E-MORB, N-MORB, and OIB data are from Sun and McDonough (1989) [39]. The compiled xenolith data are from Yang et al., 2012a; Yang et al., 2012b; Woo et al., 2014 and Choi et al., 2005 [11-13,34]. 
The $\mathrm{Zr} / \mathrm{Nb}$ ratios of the Jeju alkaline volcanic rocks were within the range of OIB mantle sources and were far lower than those of continental crust (16.2), primitive mantle (14.8), and normalized-MORB (N-MORB) (30) [40,41] (Table 2). However, contamination from the continental crust cannot be ruled out, as the plots of $\mathrm{Ba} / \mathrm{Nb}$ vs. Th/ $\mathrm{Nb}$ indicate that the samples are within or close to the EM2 range but are slightly scattered in the direction of the continental crustal field (Figure 7).

Table 2. Representative incompatible trace-elemental ratios of Jeju Island alkaline volcanic rocks, with primitive mantle, N-MORB, E-MORB, continental crust, HIMU-OIB, EM1-OIB, and EM2-OIB values for comparison.

\begin{tabular}{cccccccccc}
\hline & $\mathbf{Z r} / \mathbf{N b}$ & $\mathbf{L a} / \mathbf{N b}$ & $\mathbf{B a} / \mathbf{N b}$ & $\mathbf{B a} / \mathbf{T h}$ & $\mathbf{R b} / \mathbf{N b}$ & $\mathbf{K} / \mathbf{N b}$ & $\mathbf{T h} / \mathbf{N b}$ & $\mathbf{T h} / \mathbf{L a}$ & $\mathbf{B a} / \mathbf{L a}$ \\
\hline $\begin{array}{c}\text { Primitive } \\
\text { mantle * }\end{array}$ & 14.8 & 0.94 & 9 & 77 & 0.91 & 323 & 0.117 & 0.125 \\
N-MORB * $_{\text {E-MORB * }}$ & 30 & 1.07 & $1.7-8.0$ & 60 & 0.36 & $210-350$ & $0.025-0.071$ & 0.067 \\
$\begin{array}{c}\text { Continental } \\
\text { crust * }\end{array}$ & 16.2 & 2.2 & 54 & 124 & 4.7 & 1341 & 0.44 & 0.204 \\
HIMU-OIB * & $3.2-5.0$ & $0.66-0.77$ & $4.9-6.9$ & $49-77$ & $0.35-0.38$ & $77-179$ & $0.078-0.101$ & $0.107-0.133$ & $6.8-8.7$ \\
EM1-OIB * & $1.2-11.5$ & $0.86-1.19$ & $11.4-17.8$ & $103-154$ & $0.88-1.17$ & $213-432$ & $0.105-0.122$ & $0.107-0.128$ & $13.2-16.9$ \\
EM2-OIB * & $4.5-7.3$ & $0.89-1.09$ & $7.3-13.3$ & $67-84$ & $0.59-0.85$ & $248-378$ & $0.111-0.157$ & $0.122-0.163$ & $8.3-11.3$ \\
\hline Jeju Island alk. & $3.9-7.4$ & $0.86-1.35$ & $9.4-18.3$ & $49-154$ & $0.87-1.96$ & $394-652$ & $0.108-0.204$ & $0.111-0.177$ & $6.9-20.1$ \\
$\quad$ volcanics & 5.5 & 1.05 & 12.9 & 88 & 1.22 & 501 & 0.152 & 0.146 \\
Average of Jeju & & & $4.9-8.5$ & & & $205-230$ & $0.06-0.08$ & 12.7 \\
\hline
\end{tabular}

* Data are from Saunders et al. (1988) and Weaver (1991a) [40,41].

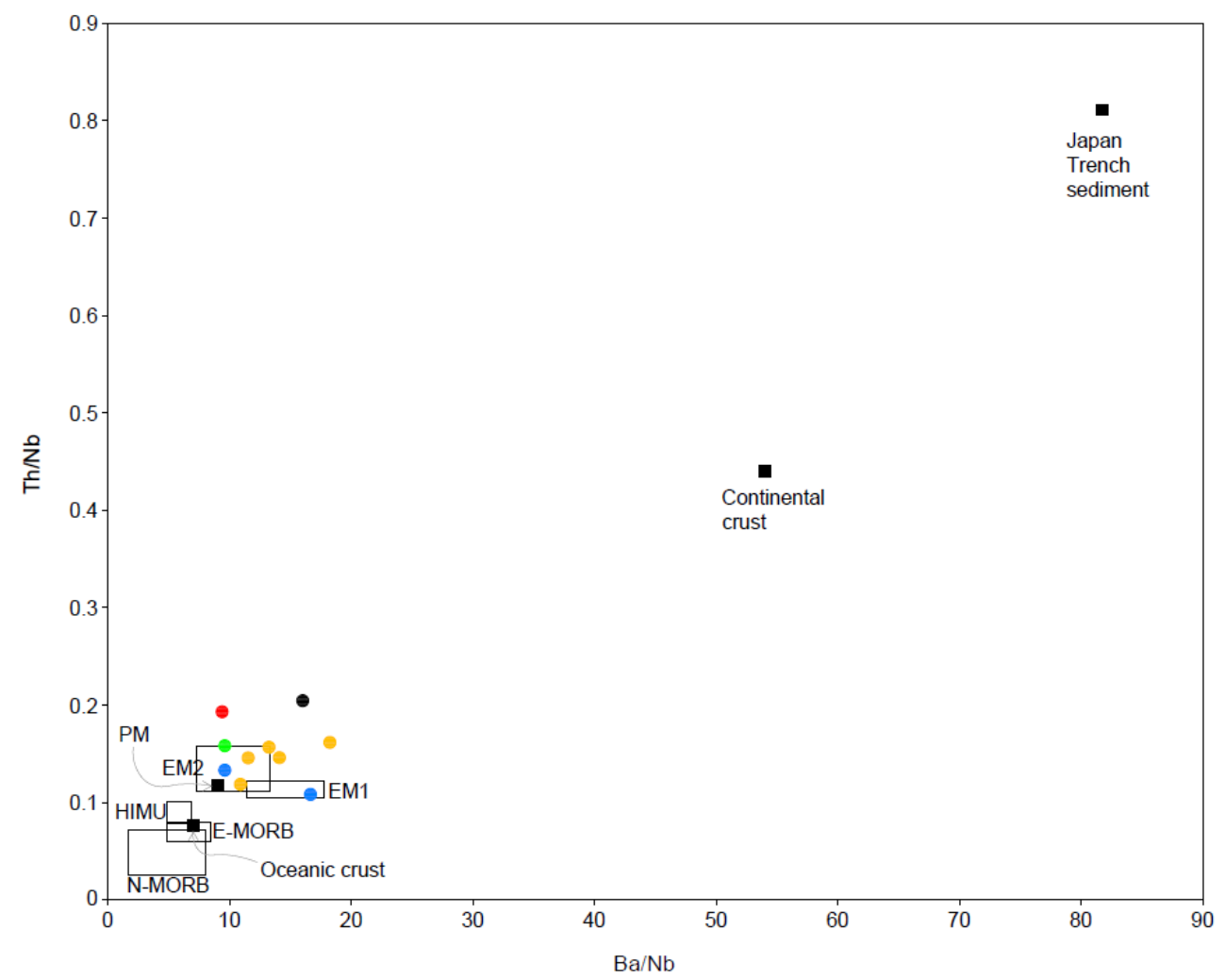

Figure 7. $\mathrm{Ba} / \mathrm{Nb}$ vs. Th/ $\mathrm{Nb}$ ratios. The data for the primitive mantle (PM), E-MORB, N-MORB, HIMU, EM1, EM2, and continental crust (CC) are from compilations by Saunders et al. (1988), Weaver (1991a), Plank and Langmuir (1998), and White et al. (2014) [40-43]. Symbols are the same as in Figure 2. 


\section{Discussion}

\subsection{Fractional Crystallization and Crustal Contamination}

$\mathrm{TiO}_{2}$ was low in the tephriphonolite and trachyte, indicating that Fe-Ti minerals (titanomagnetite) were removed by fractional crystallization (Table 1; Figure 4f). Basaltic trachyandesite, tephrite, and trachybasalt are believed to have formed from basaltic magma. The $\mathrm{Fe}_{2} \mathrm{O}_{3}$ and $\mathrm{MgO}$ contents were low in tephriphonolite and trachyte, as they are not directly related to basaltic magma and can be related to the fractional crystallization of basaltic magma (Table 1; Figure 4c,g). In addition, the tephriphonolite and trachyte had higher LREE and HREE concentrations than the basaltic trachyandesite, tephrite, and trachybasalt (Figure 5). The $(\mathrm{La} / \mathrm{Sm})_{\mathrm{N}}$ and $(\mathrm{La} / \mathrm{Lu})_{\mathrm{N}}$ ratios were also higher in the tephriphonolite and trachyte, which suggests that they were produced by a later stage of fractional crystallization from the parent magma (Table 1). The REE and multi-elemental diagrams (Figures 5 and 6 ) indicate that the volcanic rock samples were derived from OIB.

The negative anomalies of Sr and Ti observed in the samples of the most-evolved rocks (tephriphonolite and trachyte) were caused by the fractional crystallization of plagioclase and titanomagnetite, respectively, rather than by a particular magmatic environment.

Except for Sr and Ti depletions in those two samples, all of the samples display similar trends on the spidergram (Figure 6), which indicates that they were derived from the same magma source. The $\mathrm{Th} / \mathrm{Nb}$ vs. $\mathrm{Ba} / \mathrm{Nb}$ ratios also indicate that the volcanic rocks originated mainly from an enriched-mantle (EM1, EM2) source and were slightly affected by the continental crust (Figure 7).

No depletion of HFSEs (as shown in Figure 6) and no negative Eu anomaly except in the trachyte sample (as shown in Figure 5) were observed. Therefore, the magma of Jeju volcanism is thought to originate from the spinel peridotite in the upper mantle.

The two mantle xenolith samples displayed relatively depleted REE and trace-elemental patterns but similar trends to the volcanic rocks, which indicates that the xenoliths and the volcanic rocks are related in their origins. The basaltic melt most likely originated from partial melting of the upper mantle, represented by the xenoliths. However, the patterns of the xenoliths obtained in this study on the spidergram (Figure 6) and REE diagram (Figure 5) were different from those of xenoliths described in previous studies of Yang et al., 2012a; Yang et al., 2012b; Woo et al., 2014 and Choi et al., 2005 [11-13,34]. Woo et al. (2014) divided xenoliths from Jeju Island into three groups [13]: the first group comprises Cr-diopside and spinel-bearing ultramafic xenoliths that correspond to fragments of peridotitic mantle, corresponding to Group I of Frey and Prinz (1978) [44]; the second group, which contain Al-Ti-rich black clinopyroxenes, are magmatic cumulates reported to have directly crystallized near the Moho [12] and correspond to Group II of Frey and Prinz (1978) [44]; and the third group comprises gabbroic xenoliths reported to have crystallized in the reservoir-roof environment within the crust [11].

The xenolith samples of this study fall into the first group of Woo et al. (2014) [13], and the rock types are dunite and harzburgite of spinel peridotite. However, they exhibited larger depletions in MREE, HREE, and some HFSEs (Figures 5 and 6) compared to the Group I xenoliths of Yang et al. (2012a) [11] and the two other xenolith groups of Jeju Island (shaded gray areas in Figures 5 and 6), which needs to be further investigated.

The positive anomalies in $\mathrm{U}$ and $\mathrm{Pb}$, which are fluid-mobile elements (FMEs), in the whole-rock phases of xenoliths indicate that those elements have been added by a subduction component related to mantle contamination by subduction fluids [45,46]. A slight negative $\mathrm{Nb}$ anomaly, which is typical of arc magmatism, is also observed. This subduction signature was probably acquired during arc magmatism in the upper mantle during the late Cretaceous and early Tertiary [22-24].

Yang et al. (2012b) estimated the depth of the Jeju magma chamber to equal the depth of the lower continental crust [12]. Therefore, assimilation of the lower continental crust cannot be ruled out during the fractional crystallization of Jeju magma. 
By using the FC-AFC-FCA and mixing modeler [47], we estimated the relative ratio of assimilated material (lower continental crust) to crystallized material (" $r$ ") in the AFC process of magmatic evolution.

AFC modeling was carried out with the average trace element concentration of the two xenolith samples as the source of magma and with the lower continental crust as the contaminant in the equation from DePaolo (1981) [48]:

$$
\mathrm{C}_{\mathrm{L}}=\mathrm{C}_{0} \cdot \mathrm{f}+\frac{\mathrm{r}}{(\mathrm{r}-1+\mathrm{D})} \cdot \mathrm{C}_{\mathrm{A}}(1-\mathrm{f})
$$

where $C_{L}$ is the concentration of the trace element in the resulting magma; $C_{0}$ is the concentration of the trace element in the remaining melt and the original magma, respectively; $\mathrm{C}_{\mathrm{A}}$ is concentration of trace element in the contaminant, $\mathrm{r}$ is the ratio of rate of assimilation to rate of fractional crystallization; $\mathrm{f}$ is $\mathrm{F}[-(\mathrm{r}-1+\mathrm{D}) /(\mathrm{r}-1)]$; $\mathrm{F}$ is the fraction of magma remaining; and $\mathrm{D}$ is the bulk distribution coefficient for the fractionating assemblage [48].

In Figure $8, \mathrm{Zr}, \mathrm{Nb}$, and $\mathrm{La}$ values are plotted for $\mathrm{r}=0.2(\mathrm{Zr}$ vs. $\mathrm{Nb})$ and $\mathrm{r}=0.3$ (La vs. $\mathrm{Nb}$ ). The partition coefficients of $\mathrm{Zr}, \mathrm{Nb}$, and $\mathrm{La}$ are referred from Zanetti et al. (2004), McKenzie and O'Nions (1991), Villemant (1988), Foley et al.(1996), Rollinson (1993), and Zack and Brumm (1998) [49-54]. The $\mathrm{C}_{\mathrm{A}}$ values of $\mathrm{Zr}, \mathrm{Nb}$, and $\mathrm{La}$ of the lower continental crust are referred from Taylor and McLennan (1995) [55].
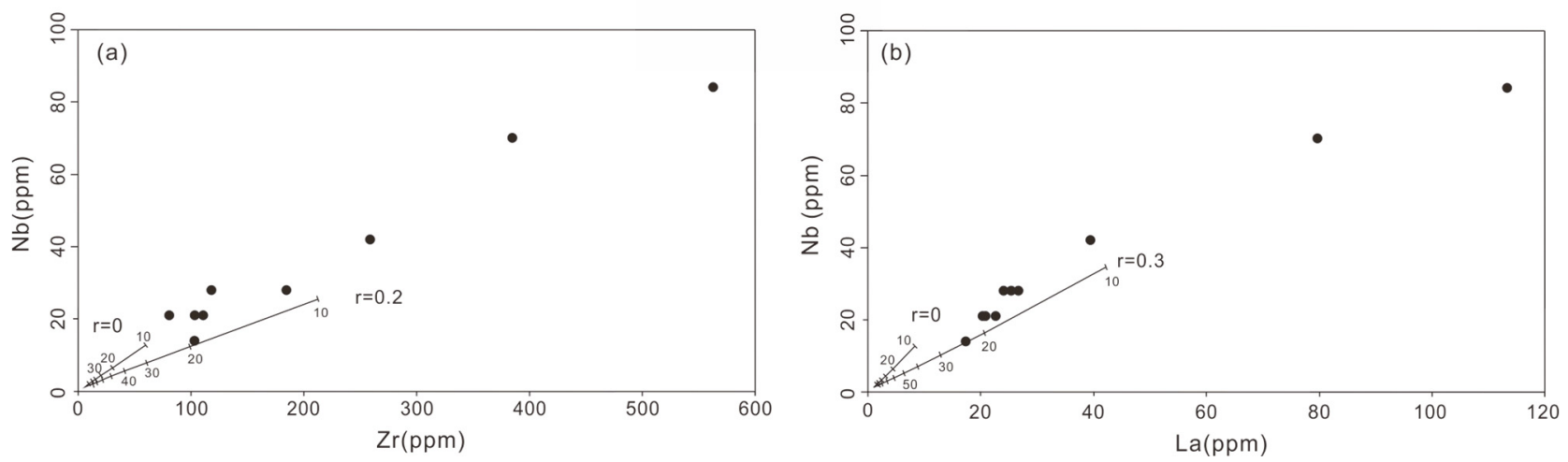

Figure 8. Plots of $\mathrm{Zr}$ vs. $\mathrm{Nb}$ contents (a) and La vs. $\mathrm{Nb}$ contents (b) for the volcanic rocks from Jeju Island by the FC-AFC-FCA and mixing modeler [47]. A 10\% increment is marked in the trajectory of AFC $(r>0)$ and FC $(r=0)$.

The figure indicates that the ratio of the assimilation rate of continental crust to the fractional crystallization rate in Jeju magma is $0-0.3$.

\subsection{Potential Magma Source}

All of the samples formed within Stages 2 and 3 of Tatsumi et al. (2005) [16], during which basaltic lavas (Pyosunri basalt) formed the bulk of the exposed volcanic rocks as a lava plateau, and volcanic rocks (basalts, trachyandesites, and trachytes) formed the Halla shield volcano. Geochemical studies regarding continental alkaline suites have shown that alkaline rocks evolve along a lineage of strong silica-undersaturated basanite to phonolite, or along a lineage of a more silica-saturated alkali basalt to trachyte $[56,57]$. The major and trace-elemental compositions of the evolved rocks can be attributed to the fractional crystallization of mafic rocks dominated by olivine, clinopyroxene, apatite, and Fe-Ti oxides, as well as to plagioclase fractionation in intermediate rocks, while the fractionation of plagioclase, alkali feldspar, zircon, and sphene may have been controlled in the highly evolved rocks [58].

By studying seismic-wave velocities, Song et al. (2018) suggested that edge-driven convective flow at sub-lithospheric depths at the lithospheric thickness transition below the island led to decompression melting [31]. The complex and dispersed intraplate volcanism 
on Jeju Island can be attributed to the intense interaction between the ascending magma and the lithosphere.

This study obtained geochemical signatures of volcanism due to FC, with crustal contamination from the lower crust, based on the REE and trace-elemental patterns of volcanic rocks and mantle xenoliths. The chondrite-normalized REE diagrams (Figure 5) indicate an OIB source.

The volcanic rocks had an enriched-mantle-2-like ocean island basalt signature and the basalt was formed by partial melting of the upper mantle, which is represented by the xenolith samples of our study. The upper mantle of Jeju was affected by arc magmatism, which is associated with the subduction of the Pacific Plate beneath the Eurasian Plate.

Comparisons of incompatible and trace-elemental ratios in the basalts and different mantle and crustal sources, including primitive mantle, N-MORB, E-MORB, continental crust, HIMU-OIB, EM1-OIB, and EM2-OIB on Jeju Island are shown in Table 2. The EM1OIB endmember component was assumed to be related to an ancient SCLM [59-61] and/or to a metasomatized lower portion of an old SCLM [61,62]. Alternatively, it may be attributable to the metasomatic enrichment of ancient oceanic lithospheric mantle from long-term storage in the deep mantle [21,63]. The EM-2 OIB endmember component was generally regarded as originating from an enriched-mantle source that was metasomatized by subduction-related melt and/or fluids [61,64], or from terrigenous sediment-bearing subducted oceanic lithosphere [64-66].

The trace-elemental ratios of the Jeju Island volcanic rocks were similar to those of an EM2-OIB source. Their $\mathrm{Th} / \mathrm{Nb}$ and $\mathrm{Th} / \mathrm{La}$ ratios were also within the range of values for the EM2-OIB source (Table 2). Nearly all of the samples plotted within or near the EM-2 OIB field in the $\mathrm{Ba} / \mathrm{Nb}-\mathrm{Th} / \mathrm{Nb}$ diagram and were scattered toward the continental crust field (Figure 7). This indicates that the Jeju Island volcanic rocks are mainly the result of AFC of an EM2-OIB source.

The isotopic ratios of Jeju volcanic rocks can be explained as a mixture of DMM and EM2, but the analyses of source mantle reservoirs vary [17]. The volcanic rocks of this study show that the Jeju alkali rocks formed from a partially melted upper-mantle source.

\section{Conclusions}

Although the alkaline volcanic rocks of Jeju Island exhibited a wide range of $\mathrm{SiO}_{2}$ contents (47.82-61.94 wt.\%), they formed from the FC of a single parent magma with continental crustal contamination. AFC modeling shows the relative ratio of assimilated material (lower continental crust) to crystallized material is $0-0.3$. The Jeju volcanic rocks have EM2-like OIB signatures, which was likely related to the extension of the Japan back-arc basin. The mantle xenoliths from the upper mantle beneath Jeju Island show depleted concentration of trace elements and REE but similar patterns to the volcanic rocks. Hence, the origin of Jeju magma is linked to the upper mantle, represented by the basaltic xenoliths. The upper mantle below Jeju Island was affected by arc magmatism which is associated with the subduction of the Pacific Plate. Therefore, we can infer two separate magmatic events occurred on Jeju Island: one associated with the subduction of the Pacific Plate beneath the Eurasian Plate (represented by xenoliths) in late Cretaceous and early Tertial and another associated with a divergent setting during which intraplate magmatism occurred by partial melting of the upper mantle (represented by the host rocks) in Quaternary (Figure 9). Further study of the mantle xenoliths on Jeju Island is required, as the REE and trace-elemental signatures of the xenoliths reported in this study differ from those reported by previous studies. 


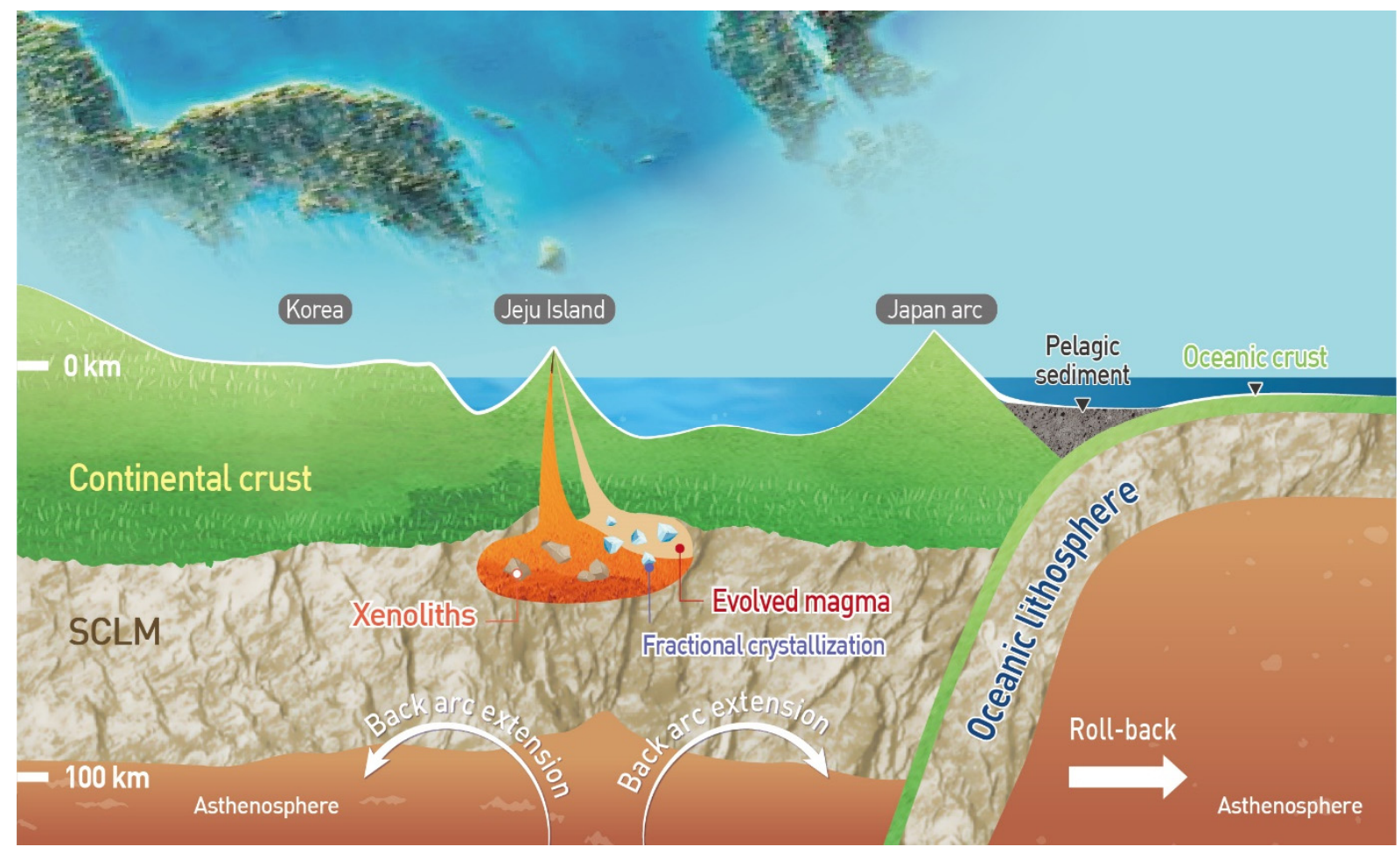

Figure 9. Schematic diagram illustrating the origin of the alkaline volcanic rocks and mantle xenoliths on Jeju Island based on the results of this study (not to scale).

Author Contributions: Conceptualization, C.K. and C.L.; methodology, N.A.K. and Y.J.; software, C.L.; validation, H.K., Y.J. and C.L.; formal analysis, C.K.; investigation, N.A.K.; resources, C.K.; data curation, C.K.; writing-original draft preparation, C.K. and N.A.K.; writing-review and editing, H.K.; visualization, C.L.; supervision, C.L.; project administration, C.L.; funding acquisition, C.L. and H.K. All authors have read and agreed to the published version of the manuscript.

Funding: This work was supported by the Basic Science Research Program through the National Research Foundation of Korea (NRF) funded by the Ministry of Education [grant numbers 2016R1D1A1B01010469, 2019R1A61A03033167] and the Korea Ministry of Environment, through the strategic EcoSSSoil Project, KEITI (Korea Environmental Industry and Technology Institute), Korea (Grant No. 2019002820004).

Conflicts of Interest: The authors declare that they have no known competing financial interests or personal relationships that could have appeared to influence the work reported in this paper.

\section{References}

1. Woo, K.; Sohn, Y.; Ahn, U.; Yoon, S.; Spate, A. Geology of Jeju Island. In Jeju Island Geopark-A Volcanic Wonder of Korea. Geoparks of the World; Springer: Berlin/Heidelberg, Germany, 2013.

2. Nakamura, S. Note on Saishu, volcanic island. Globe 1925, 4, 325-336.

3. Lee, S.M. Volcanic rocks in Cheju Island, Korea. J. Geol. Soc. Korea 1966, 2, 1-7, (In Korean with English abstract).

4. Kim, B.K. A stratigraphic and paleontological study of the Sinyangri and Gosanri Formation in the vicinity of Sinyangri in the Jeju Island. J. Geol. Soc. Korea 1969, 15, 103-121. (In Korean)

5. Kim, B.K. Paleontological study on the sand dune deposits in Jeju Island. J. Geol. Soc. Korea 1974, 10, 95-103. (In Korean)

6. Taneda, S.; Tsuji, K.; Nakamura, M. Geological, petrological and paleomagnetic studies on the volcanic rocks of Cheju Island. Bull. Volcanol. Soc. Jpn. 1970, 2, 96-108.

7. Won, C.K. Study of geologic development and the volcanic activity of the Jeju Island. J. Sci. Kun Kook Univ. 1975, 1, 7-48.

8. Lee, S.K. A Study of Gravity, Crustal Structure and Isostasy of Jeju Island, Korea. Master's Thesis, Seoul National University, Seoul, Korea, 1981.

9. Lee, M.W. Geology of Jeju volcanic island, Korea. J. Jpn. Assoc. Mineral. Petrol. Econ. Geol. 1982, 77, 55-64. (In Japanese) [CrossRef]

10. Lee, M.W. Petrology of Jeju volcanic island, Korea, Part 1, Petrography and bulk chemical composition. J. Jpn. Assoc. Mineral. Petrol. Econ. Geol. 1982, 77, 203-214. (In Japanese) [CrossRef] 
11. Yang, K.; Arai, S.; Yu, J.-E.; Yun, S.-H.; Kim, J.-S.; Hwang, J.-Y. Gabbroic xenoliths and megacrysts in the Pleisto-Holocene alkali basalts from Jeju Island, South Korea: The implications for metasomatism of the lower continental crust. Lithos 2012, 142-143, 201-215. [CrossRef]

12. Yang, K.H.; Szabo, C.; Arai, S.; Yu, J.E.; Jung, H.Y. Silica enrichment of Group II xenoliths by evolved alkali bas-alt from Jeju Island, South Korea: Implication for modification of intraplate deep-seated rocks. Mineral. Petrol. 2012, 106, 107-130. [CrossRef]

13. Woo, Y.; Yang, K.; Kil, Y.; Yun, S.-H.; Arai, S. Silica- and LREE-enriched spinel peridotite xenoliths from the Quaternary intraplate alkali basalt, Jeju Island, South Korea: Old subarc fragments? Lithos 2014, 208-209, 312-323. [CrossRef]

14. Brenna, M.; Cronin, S.; Kereszturi, G.; Sohn, Y.K.; Smith, I.; Wijbrans, J. Intraplate volcanism influenced by distal subduction tectonics at Jeju Island, Republic of Korea. Bull. Volcanol. 2015, 77, 1-16. [CrossRef]

15. Park, J.B.; Kwon, S.T. Geochemical evolution of the Cheju volcanic island: Petrography and major element chemistry for stratigraphically-controlled lavas from the northern part of Cheju Island. J. Geol. Soc. Korea 1993, 29, 39-60. (In Korean)

16. Tatsumi, Y.; Shukuno, H.; Yoshikawa, M.; Chang, Q.; Sato, K.; Lee, M.W. The petrology and geochemistry of vol-canic rocks on Jeju Island: Plume magmatism along the Asian continental margin. J. Petrol. 2005, 46, 523-553. [CrossRef]

17. Choi, S.H.; Mukasa, S.B.; Kwon, S.-T.; Andronikov, A.V. Sr, Nd, Pb and Hf isotopic compositions of late cenozoic alkali basalts in South Korea: Evidence for mixing between the two dominant asthenospheric mantle domains beneath East Asia. Chem. Geol. 2006, 232, 134-151. [CrossRef]

18. Koh, G.W.; Park, J.B.; Kang, B.R.; Kim, G.P.; Moon, D.C. Volcanism in Jeju Island. J. Geol. Soc. Korea 2013, 49, 209-230. (In Korean)

19. Lee, W.M. Petrology and geochemistry of Jeju volcanic island, Korea. Sci. Rep. Tohoku Univ. Ser. III 1982, 15, 177-256. (In Japanese)

20. Baek, S.; Choi, S.H.; Lee, S.G.; Lee, S.R.; Lee, H.M. Geochemistry of anorthositic xenoliths and host tholeiite bas-alt from Jeju Island, South Korea. Geosci. J. 2014, 18, 125-135. [CrossRef]

21. Kim, J.-I.; Choi, S.H.; Koh, G.W.; Park, J.B.; Ryu, J.-S. Petrogenesis and mantle source characteristics of volcanic rocks on Jeju Island, South Korea. Lithos 2019, 326-327, 476-490. [CrossRef]

22. Koh, K.; Park, Y.; Park, O. The underground geology and 40Ar-39Ar dating from the eastern part of Jeju Island. Spring geological field trip. J. Geol. Soc. Korea 2004, 29-50. (In Korean)

23. Sibuet, J.-C.; Letouzey, J.; Barbier, F.; Charvet, J.; Foucher, J.-P.; Hilde, T.W.C.; Kimura, M.; Chiao, L.-Y.; Marsset, B.; Muller, C.; et al. Back arc extension in the okinawa trough. J. Geophys. Res. Space Phys. 1987, 92, 14041-14063. [CrossRef]

24. Kim, K.H.; Tanaka, T.; Suzuki, K.; Nagao, K.; Park, E.J. Evidences of the presence of old continental basement in Cheju volcanic Island, South Korea, revealed by radiometric ages and Nd-Sr isotopes of granitic rocks. Geochem. J. 2002, 36, 421-441. [CrossRef]

25. Park, J.B. Geochemical Evolution of the Cheju Volcanic Island, Korea. Ph.D. Thesis, Yonsei University, Seoul, Korea, 1994.

26. Nakamura, E.; Campbell, I.; McCulloch, M.; Sun, S.-S. Chemical geodynamics in a back arc region around the Sea of Japan: Implications for the genesis of alkaline basalts in Japan, Korea, and China. J. Geophys. Res. Space Phys. 1989, 94, $4634-4654$. [CrossRef]

27. Brenna, M.; Cronin, S.; Smith, I.; Maas, R.; Sohn, Y.K. How small-volume basaltic magmatic systems develop: A case study from the Jeju Island Volcanic Field, Korea. J. Pet. 2012, 53, 985-1018. [CrossRef]

28. Brenna, M.; Cronin, S.J.; Smith, I.; Sohn, Y.K.; Maas, R. Spatio-temporal evolution of a dispersed magmatic system and its implications for volcano growth, Jeju Island Volcanic Field, Korea. Lithos 2012, 148, 337-352. [CrossRef]

29. Won, J.K.; Matsuda, J.; Nagao, K.; Kim, K.H.; Lee, M.W. Paleomagnetism and radiometric age of trachytes in Jeju Island, Korea. Korean Soc. Econ. Environ. Geol. 1986, 19, 25-33. (In Korean)

30. Kim, Y.; Lee, C.; Kim, S.-S. Tectonics and volcanism in East Asia: Insights from geophysical observations. J. Asian Earth Sci. 2015, 113, 842-856. [CrossRef]

31. Song, J.H.; Kim, S.; Rhie, J.; Lee, S.H.; Kim, Y.H.; Kang, T.S. Imaging of lithospheric structure beneath Jeju vol-canic island by teleseismic traveltime tomography. J. Geophys. Res. Solid Earth 2018, 123, 6784-6801.

32. Sohn, Y.K.; Park, K.H. Early-stage volcanism and sedimentation of Jeju Island revealed by the Sagye borehole, SW Jeju Island, Korea. Geosci. J. 2004, 8, 73-84. [CrossRef]

33. Sohn, Y.K.; Park, K.H.; Yoon, S.H. Primary versus secondary and subaerial versus submarine hydrovolcanic de-posits in the subsurface of Jeju Island, Korea. Sedimentology 2008, 55, 899-924. [CrossRef]

34. Choi, S.H.; Kwon, S.T.; Mukasa, S.B.; Sagong, H. Sr-Nd-Pb isotope and trace element systematics of mantle xenoliths from late Cenozoic alkaline lavas, South Korea. Chem. Geol. 2005, 221, 40-64. [CrossRef]

35. Kim, Y.S.; Choi, S.H. Plagioclase-rich nodules in Taeheungri basalt from Namwon, Jeju Island and its implica-tions for tholeiite magmatism. J. Geol. Soc. Korea 2012, 48, 313-324. (In Korean)

36. Park, K.H.; Lee, B.J.; Kim, J.C.; Cho, D.L.; Lee, S.R.; Park, D.W.; Lee, S.; Choi, Y.S.; Yeum, D.Y.; Kim, J.Y.; et al. Explanatory Note of the Jeju (Baekado, Jinnampo Sheet) (1:250,000). Korea Inst. Geol. Min. Mater. 2000, 1-59.

37. Bas, M.J.L.; Maitre, R.W.L.; Streckeisen, A.; Zanettin, B.; IUGS Subcommission on the Systematics of Igneous Rocks. A chemical classification of volcanic rocks based on the total alkali-silica diagram. J. Pet. 1986, 27, 745-750. [CrossRef]

38. Irvine, T.N.; Baragar, W.R.A. A guide to the chemical classification of the common volcanic rocks. Can. J. Earth Sci. 1971, 8, 523-548. [CrossRef]

39. Sun, S.S.; McDonough, W.F. Chemical and isotopic systematics of oceanic basalts: Implications for mantle com-position and processes. Geol. Soc. Lond. Spec. Publ. 1989, 42, 313-345. [CrossRef] 
40. Saunders, A.D.; Norry, M.J.; Tarney, J. Origin of MORB and chemically-depleted mantle reservoirs: Trace element constraints. J. Pet. 1988, 1, 415-445. [CrossRef]

41. Weaver, B.L. The origin of ocean island basalt end-member compositions: Trace element and isotopic constraints. Earth Planet. Sci. Lett. 1991, 104, 381-397. [CrossRef]

42. Plank, T.; Langmuir, C.H. The chemical composition of subducting sediment and its consequences for the crust and mantle. Chem. Geol. 1998, 145, 325-394. [CrossRef]

43. White, W.M.; Klein, E.M.; Holland, H.D.; Turekian, K.K. 4.13-Composition of the oceanic crust. Treatise Geo-Chem. 2014, 4, 457-496.

44. Frey, F.; Prinz, M. Ultramafic inclusions from San Carlos, Arizona: Petrologic and geochemical data bearing on their petrogenesis. Earth Planet. Sci. Lett. 1978, 38, 129-176. [CrossRef]

45. El Dien, H.G.; Li, Z.-X.; Kil, Y.; Abu-Alam, T. Origin of arc magmatic signature: A temperature-dependent process for trace element (re)-mobilization in subduction zones. Sci. Rep. 2019, 9, 1-12. [CrossRef]

46. Secchiari, A.; Montanini, A.; Bosch, D.; Macera, P.; Cluzel, D. Sr, Nd, Pb and trace element systematics of the New Caledonia harzburgites: Tracking source depletion and contamination processes in a SSZ setting. Geosci. Front. 2020, 11, 37-55. [CrossRef]

47. Ersoy, Y.; Helvac1, C. FC-AFC-FCA and mixing modeler: A Microsoft ${ }^{\circledR}$ Excel $^{\circledR}$ spreadsheet program for modeling geochemical differentiation of magma by crystal fractionation, crustal assimilation and mixing. Comput. Geosci. 2010, 36, 383-390. [CrossRef]

48. DePaolo, D.J. Trace element and isotopic effects of combined wallrock assimilation and fractional crystallization. Earth Planet. Sci. Lett. 1981, 53, 189-202. [CrossRef]

49. Zanetti, A.; Tiepolo, M.; Oberti, R.; Vannucci, R. Trace-element partitioning in olivine: Model-ling of a complete data set from a synthetic hydrous basanite melt. Lithos 2004, 75, 39-54. [CrossRef]

50. McKenzie, D.A.N.; O'nions, R.K. Partial melt distributions from inversion of rare earth element concentra-tions. J. Petrol. 1991, 32, 1021-1091. [CrossRef]

51. Villemant, B. Trace element evolution in the Phlegrean Fields (Central Italy): Fractional crystallization and selective enrichment. Contrib. Miner. Pet. 1988, 98, 169-183. [CrossRef]

52. Foley, S.F.; Jackson, S.M.; Fryer, B.J.; Greenouch, J.D.; Jenner, G.A. Trace element partition coef-ficients for clinopyroxene and phlogopite in an alkaline lamprophyre from Newfoundland by LAM-ICP-MS. Geochim. Et Cosmochim. Acta 1996, 60, 629-638. [CrossRef]

53. Rollinson, H.R. Using Geochemical Data: Evaluation, Presentation, Interpretation; Routledge: London, UK, 1993.

54. Zack, T.; Brumm, R. Ilmenite/liquid partition coefficients of 26 trace elements determined through ilmenite/clinopyroxene partitioning in garnet pyroxenites. In International Kimberlite Conference: Extended Abstracts; IKC: Cape Town, South Africa, 1998; Volume 7, pp. 986-988.

55. Taylor, S.R.; McLennan, S. The geochemical evolution of the continental crust. Rev. Geophys. 1995, 33, 241-265. [CrossRef]

56. Wilson, M.; Downes, H.; Cebriá, J.-M. Contrasting fractionation trends in coexisting continental alkaline magma series; Cantal, Massif Central, France. J. Pet. 1995, 36, 1729-1753. [CrossRef]

57. Panter, K.S.; Kyle, P.R.; Smellie, J.L. Petrogenesis of a phonolite-trachyte succession at Mount Sidley, Marie Byrd Land, Antarctica. J. Petrol. 1997, 38, 1225-1253. [CrossRef]

58. Freundt, A.; Schmincke, H.-U. Petrogenesis of rhyolite-trachyte-basalt composite ignimbrite P1, Gran Canada, Canary Islands. J. Geophys. Res. Space Phys. 1995, 100, 455-474. [CrossRef]

59. Song, Y.; Frey, F.; Zhi, X. Isotopic characteristics of Hannuoba basalts, eastern China: Implications for their petrogenesis and the composition of subcontinental mantle. Chem. Geol. 1990, 88, 35-52. [CrossRef]

60. Basu, A.R.; Junwen, W.; Wankang, H.; Guanghong, X.; Tatsumoto, M. Major element, REE, and Pb, Nd and Sr iso-topic geochemistry of Cenozoic volcanic rocks of eastern China: Implications for their origin from suboceanic-type mantle reservoirs. Earth Planet. Sci. Lett. 1991, 105, 149-169. [CrossRef]

61. Derakhshi, M.; Ghasemi, H.; Miao, L. Geochemistry and petrogenesis of Soltan Maidan basalts (E Alborz, Iran): Implications for asthenosphere-lithosphere interaction and rifting along the N margin of Gondwana. Geochemistry 2017, 77, 131-145. [CrossRef]

62. Tatsumoto, M.; Nakamura, Y. DUPAL anomaly in the sea of Japan: $\mathrm{Pb}, \mathrm{Nd}$, and $\mathrm{Sr}$ isotopic variations at the eastern Eurasian continental margin. Geochim. Et Cosmochim. Acta 1991, 55, 3697-3708. [CrossRef]

63. Niu, Y.; O'Hara, M.J.; Pearce, J.A. Initiation of subduction zones as a consequence of lateral compositional buoyancy contrast within the lithosphere: A petrological perspective. J. Pet. 2003, 44, 851-866. [CrossRef]

64. Weaver, B.L. Trace element evidence for the origin of ocean-island basalts. Geology 1991, 19, 123-126. [CrossRef]

65. Workman, R.K.; Eiler, J.M.; Hart, S.R.; Jackson, M.G. Oxygen isotopes in Samoan lavas: Confirmation of conti-nent recycling. Geology 2008, 36, 551-554. [CrossRef]

66. Zindler, A.; Hart, S. Chemical geodynamics. Annu. Rev. Earth Planet. Sci. 1986, 14, 493-571. [CrossRef] 